\author{
Anna Ząbkowicz \\ Uniwersytet Jagielloński \\ e-mail: anna.zabkowicz@uj.edu.pl
}

\title{
INSTYTUCJONALNY KONTEKST FUNKCJONOWANIA RYNKU I ORGANIZACYJNE FORMY KOORDYNACJI JAKO ELEMENTY NOWEGO PARADYGMATU W EKONOMII
}

\author{
INSTITUTIONAL CONTEXT OF MARKET \\ FUNCTIONING AND ORGANIZATIONAL \\ COORDINATION FORMS AS ELEMENTS \\ OF A NEW PARADIGM IN THE ECONOMICS
}

DOI: $10.15611 / \mathrm{pn} .2015 .405 .01$

Streszczenie: Analiza ma na celu wykazanie tych cech instytucjonalizmu w ekonomii, które mogą wskazywać, że wyłania się nowy paradygmat. Artykuł zawiera zarys instytucjonalistycznego programu badawczego ze wskazaniem na główne pojęcie organizujące. Dowodzi, że oryginalne osiągnięcie nowej ekonomii instytucjonalnej, jakim jest pojęcie governance structure, jest użyteczne przy modelowym przedstawieniu aktywności gospodarczej i dlatego stanowi inspirację do budowy nowego paradygmatu w wąskim pragmatycznym rozumieniu. Zdyscyplinowanie myśli ekonomicznej za pomocą proponowanego schematu obiecuje względnie proste ramy analityczne, które sprowadzają aktywność gospodarczą na każdym podstawowym poziomie do modelu. Ten wynik osiągnięto z jednej strony dzięki analizie klasycznych lektur z dziedziny ekonomii instytucjonalnej i dzięki próbie dokonania syntezy $\mathrm{z}$ drugiej strony.

Słowa kluczowe: struktury zarządzania, ład gospodarczy, ekonomia instytucjonalna.

Summary: The research is carried on the attributes of institutional economic thinking which can suggest a new paradigm in economics emerging. The characteristics of institutional research program is sketched, with indication to its central concept. It is argued that governance structure which is the original concept of new institutional economics is useful in designing a model of economic activities, and thus it appears to be the idea for a new paradigm building in the narrow pragmatic sense. Disciplining economic analysis along these lines promises rather simple framework which reduces the coordination of economic activities on every basic level to a model. This outcome has been reached in the result of analytical work on classical economic-institutional readings on the one hand and of an attempt to synthesize on the other.

Keywords: governance structures, economic order, institutional economics. 


\section{Wstęp}

Nauka ekonomii skonsolidowała się wokół abstrakcyjnego pojęcia rynku. Rynek pełni funkcję, mówiąc słowami Hayeka, bezosobowego mechanizmu, koordynującego indywidualne wysiłki ludzkie i niezależnego od ludzkich sądów. Dzięki niemu gospodarka zachowuje się jak część naturalnego świata w tym sensie, że dąży do równowagi. Do tej „naturalnej” skłonności przyczyniają się konsumenci i przedsiębiorcy, a ściślej konkurencja, która jest rezultatem ich aktywności na rynku. Konkurencja stanowi potężne ograniczenie ludzkiego woluntaryzmu, ukierunkowuje indywidualne decyzje i działania ku ogólnemu dobru i w tym sensie czyni zbiorowy efekt aktywności gospodarczej obliczalnym. Taki model gospodarki daje się ująć w rygorystycznej matematycznej formie, dzięki czemu analiza prowadzi do „twardych" wniosków, na których można oprzeć działania prowadzące do społecznego dobrobytu. Tej możliwości zazdroszczą ekonomistom przedstawiciele innych nauk społecznych i humanistycznych.

Jednak ekonomia, podobnie jak inne nauki, nie jest wolna od kłopotów z własnym sposobem myślenia o rzeczywistości; ma ona przede wszystkim problem z nader abstrakcyjnym ujęciem swojego przedmiotu. Szczególnie w czasie obecnego międzynarodowego kryzysu finansowego odbieramy z gospodarki wzmożone sygnały, że trzeba dokonać rewizji tego dominującego w ekonomii myślenia. Od lat 90. XX wieku instytucjonalizm w ekonomii przeżywa renesans. Jest on dość powszechnie uważany za najbardziej liczącą się alternatywę dla głównego nurtu nauki o gospodarowaniu. Celem artykułu jest próba odpowiedzi na pytanie, jakie cechy i które elementy tego sposobu myślenia o gospodarce mogą potwierdzać przekonanie o rodzącym się nowym paradygmacie.

Bezpośrednią inspiracją do podjęcia tematu była książka Janiny Godłów-Legiędź pod tytułem Wspótczesna ekonomia. Ku nowemu paradygmatowi? Autorka tej zajmującej książki analizuje myśli wybranych prominentnych reprezentantów instytucjonalizmu w ekonomii, zawarte głównie w publikacjach z lat 90. XX wieku i z przełomu wieków. Symptomy nowego dostrzega w tym, że wskazują oni zagadnienia, takie jak rozwój umysłu (D.C. North), dostęp do dóbr duchowych (R. Fogel), pierwotny podział dochodu i polityka społeczna (E. Phelps), w charakterze ostatecznych źródeł instytucji i wzrostu materialnego [Godłów-Legiędź 2010, s. 11-12]. Podejmowanie dyskusji z tymi ustaleniami historyka myśli nie jest zamierzeniem niniejszej pracy. Wychodząc od tego samego pytania, idzie ona w innym kierunku. Przedstawia pewien projekt na podstawie innych klasycznych źródeł. W wyniku zamierzonego zawężenia opiera się w głównej mierze na współczesnej myśli O.E. Williamsona i zaliczanej do tradycyjnego instytucjonalizmu myśli J.R. Commonsa, która stworzyła jej fundamenty1. Pierwsza część artykułu przypomina, na czym polega odmienność instytucjonalistycznego myślenia o gospodarce wobec

${ }^{1}$ Innym ważnym dla Williamsona prekursorem był, jak wiadomo, R.H. Coase. 
głównego nurtu ekonomii. Wychodząc z założenia, że odmienność nie jest wystarczającym powodem do udzielenia odpowiedzi twierdzącej w interesującej nas kwestii, w części następnej stawiamy pytanie, z jakich względów podejście instytucjonalne można uznać za paradygmat.

Przez paradygmat rozumiemy tu wizję i sposób ujęcia przedmiotu badań zorganizowane wokół pewnego specyficznego pomysłu badawczego, co ma wartość eksplanacyjną. Jako przykład z dziedziny ekonomii może służyć popytowy model dochodu narodowego Keynesa, podstawa rozwoju ekonomii w pierwszych dekadach po II wojnie światowej i zarazem jedna z koncepcji uchwycenia złożonego zjawiska, jakim jest gospodarka. Według J. Godłów-Legiędź takie modelowe rozwiązanie, „powszechnie uznane osiągnięcie naukowe z przeszłości, które jako model nadal służy współczesnym uczonym", jest to najwęższe i zarazem pragmatyczne rozumienie terminu. Według tego samego źródła inny jest wymiar paradygmatu neoklasycznego, stanowiącego jak dotąd podstawę współczesnej ekonomii. Jest to „zespół charakterystycznych uprzedzeń i przekonań", w tym przede wszystkim dążenie do czystości i formalizacji nauki ,przez wyeliminowanie z procesu wyjaśniania wartości innych niż te, które są implicite zawarte w przyjętym modelu racjonalności" [Godłów-Legiędź 2010, s. 10-11]. Nie pragmatyzm zatem, lecz cały zespół instrumentalnych, technicznych i metafizycznych przekonań określa paradygmat w tym wymiarze. Wizja gospodarki rynkowej opiera się w tym przypadku na pojęciu konkurencji, o czym wzmianka padła na początku artykułu. Gwoli większej jasności należy jeszcze wspomnieć, że w najszerszym ujęciu paradygmat, któremu podobno sam Thomas Kuhn nie przypisał jednoznacznej treści, to synonim całościowego, metafizycznego obrazu świata (np. mechanistyczno-racjonalistyczna wizja świata, organiczno-ekologiczna wizja świata) [Godłów-Legiędź 2010, s. 190]. Wydaje się, że tym, co przesądza o uznaniu za paradygmat w każdym przypadku, jest akceptacja danej wizji w danym okresie przez większość badaczy.

Przy tak ambitnie zarysowanym zadaniu i wobec podjęcia go w wąskich ramach artykułu niezbędne jest zastrzeżenie. Niniejszą próbę należy traktować jako zarys i przyczynek, a nie studium. Praca ta będzie miała wartość, jeśli stworzy odniesienia do bardziej pogłębionych studiów, krytycznych uwag i sporów, bez których niemożliwe jest ustalenie paradygmatu.

\section{Jakie atrybuty wyróżniają instytucjonalistyczne podejście}

Punktem wyjścia do odpowiedzi na pytanie o nowy paradygmat powinna być kwestia, co jest przedmiotem ekonomii i na czym polega specyfika instytucjonalistycznego ujęcia. Odpowiedź wymaga odniesień do tradycji myśli ekonomicznej. Ze względu na krótką formę artykułu ograniczymy się jedynie do zasygnalizowania, jakich wskazówek dostarcza tradycyjna ekonomia odnośnie do przedmiotu swoich 
badań, i hasłowo zaledwie określimy perspektywę instytucjonalistyczną ${ }^{2}$. Przy tak ogólnym zarysie tracą sens skrupulatne rozróżnienia pomiędzy wkładem „starej” i nowej ekonomii instytucjonalnej.

Kwestia przedmiotu ekonomii nie została jednoznacznie rozstrzygnięta. Zasadniczo „[p]rzedmiotem ekonomii są ludzie: ich potrzeby, aspiracje, preferencje, wartości, zachowania, relacje miedzy jednostkami i grupami, efekty ich działania i wiele innych aspektów ludzkiej egzystencji" [Wilkin 2009, s. 301]. Ekonomia neoklasyczna zakłada, że konsumenci i przedsiębiorcy odpowiadają charakterystyce homo oeconomicus i działają na doskonale przejrzystym rynku. Instytucjonalizm rozwija się dzięki uchyleniu (tradycyjna ekonomia instytucjonalna) bądź modyfikacji (nowa ekonomia instytucjonalna) tych założeń. Podkreśla ograniczoną racjonalność ludzi w otoczeniu cechującym się złożonością i niepewnością oraz oportunizm umawiających się stron, który stanowi ważne źródło tej niepewności (R.H. Coase, O.E. Williamson). Zachowanie podmiotów ekonomicznych kształtują szeroko pojęte normy społeczne (instytucje). Z uwagi na nie wybory dokonywane przez człowieka są ograniczone lub, mówiąc inaczej, egoistyczne pobudki są modyfikowane ze względu na stosowność pod wpływem sposobów myślenia charakterystycznych dla danej grupy. Niemniej, w określonych okolicznościach człowiek skłonny jest do oportunizmu ${ }^{3}$. Podczas gdy podmiot ekonomiczny w analizach w głównym nurcie ekonomii jest jak gentleman grający w krykieta, oportunista w intelektualnej perspektywie ekonomii instytucjonalnej jest graczem, który nie waha się przed wykorzystaniem każdej przewagi.

Ekonomia jest nauką wyjaśniającą ludzkie wybory związane z wykorzystaniem rzadkich zasobów. W jej głównym nurcie siła robocza jest traktowana instrumentalnie jako jeden z czynników produkcji, można zatem powiedzieć, że uwaga skierowana jest na fizyczność raczej niż na psychologiczne więzi międzyludzkie. Instytucjonalizm (nowa historia gospodarcza, teoria publicznego wyboru, nowa teoria firmy) włącza w zakres ekonomii także wybory związane z instytucjami (zob. [Godłów-Legiędź 2010, s. 88]). Instytucje, czyli formalne i nieformalne normy postępowania, są ustanawiane, przestrzegane i łamane przez ludzi w celu rozwiązywania dylematów zbiorowego działania. Taka redefinicja przedmiotu w centrum perspektywy badawczej stawia stosunki między ludźmi i, jak słusznie wskazuje J. Godłów-Legiędź, przesuwa uwagę z jednostki na współdziałanie ludzi w rozwiązywaniu problemów alokacji zasobów. Szczególnie od wyboru prawnych zasad zależą relacje, polegające na ograniczeniu opcji (choice sets) jednostek w odniesieniu do ograniczeń wyboru innych członków społeczeństwa. Według J.R. Commonsa

2 Z klasycznych opracowań można polecić Furubotn, Richter [2000], Hall, Taylor [1996], Aoki [2001]. Stosunkowo nowe kompendium to Chavance [2009]. Z polskojęzycznych opracowań na uwagę zasługuje książka W. Stankiewicza [2004] o tradycyjnym instytucjonalizmie w ekonomii.

3 Według O.E. Williamsona oportunizm staje się problemem w niepowtarzalnych, względnie sporadycznych i zarazem wysoko wyspecjalizowanych transakcjach - przy stosunkowo niewielkiej liczbie potencjalnych dostawców. 
owe reguły (working rules) wskazują, co ,jednostki mogą i czego im nie wolno (przymus lub obowiązek), co mogą robić nie narażając się na ingerencję innych jednostek (przyzwolenie lub wolność), co są w stanie robić z pomocą władzy zbiorowości (zdolność lub prawo) i czego władza zbiorowości nie zrobi na ich rzecz (niezdolność lub narażenie się)"4 [Commons 1968, s. 6; cyt. za: Bromley 1989, s. 43].

Ekonomia od początku swego powstania próbuje objaśniać gospodarowanie $\mathrm{w}$ kapitalistycznych ramach ustrojowych. Niemniej do tej pory nie ma powszechnie podzielanej definicji, która oddawałaby istotę kapitalizmu i problem ten nie dotyczy bynajmniej tylko głównego nurtu [Hodgson 2015]. Czy istotą kapitalizmu jest powszechna wymiana towarowa i rynek, naturalnie sprzężone z pieniądzem ${ }^{5}$ ? Czy kapitalizm lepiej charakteryzuje nierówność i społeczne stosunki wyzysku, jak uważał Karol Marks? Czy ustrój ten wyróżnia raczej wolność, gotowość do zmian i do ponoszenia ryzyka, jak uważali Friedrich von Hayek i Walter Eucken? Zarówno tradycyjny instytucjonalizm, jak i nowa ekonomia instytucjonalna podzielają stanowisko Johna Commonsa, że za podstawową jednostkę analizy tego ustroju gospodarczego należy uznać transakcje, które można zdefiniować jako akty wymiany dóbr, usług, informacji bądź idei między podmiotami gospodarczymi. Znacznie pełniej niż w poprzednich fazach historycznych, gospodarka jawi się jako strumień transakcji, przy tym zarówno typ transakcji, jak i instytucjonalne formy, w jakich one przebiegają, podlegają ewolucji, co gruntownie zmienia kształt systemu ekonomicznego i rezultaty jego funkcjonowania.

Ekonomia próbuje objaśniać swój przedmiot za pomocą analizy formalnej, analizy jakościowej i metod eksperymentalnych. Tym, co wyznacza główny nurt teorii ekonomii, jest przede wszystkim metoda. To na niej, a nie na przedmiocie badań, w ocenie uznanych i poważanych profesjonalistów, koncentrują się zainteresowania w głównym nurcie (zob. [Wojtyna 2008, s. 15 i 18]). Eklektyczność głównego nurtu skłania do stawiania kwestii, czym on jest, ciągle na nowo. David Colander sporządził interesujące zestawienie, porównując siedem atrybutów historycznej szkoły neoklasycznej oraz idee podzielane współcześnie przez ekonomistów głównego nurtu. Okazało się, że większość tych atrybutów została albo porzucona, albo zmodyfikowana [Colander 2000, s. 134-136]. Natomiast instrumentarium jest konsekwentnie rozwijane. Koncepcja marginalistów, aby opisywać gospodarkę za pomocą narzędzi matematycznych, rozwinięta przez ekonomistów neoklasycznych dała podstawy w okresie powojennym do „rewolucji formalistycznej” [Landreth,

${ }^{4}$ So called working rules indicate what "individuals must and must not (compulsion or duty), what they may do without interference from other individuals (permission or liberty), what they can do with the aid of collective power (capacity or right), and what they cannot expect the collective power to do in their behalf (incapacity or exposure) [Commons 1968, s. 6].

Amartya Sen, ekonomista i filozof, noblista z 1998 roku, zwraca uwagę, że zamożne kraje świata od dawna wykorzystują umowy i inne płatności realizowane poza rynkiem; gospodarka kapitalistyczna opiera się nie tylko na maksymalizacji zysków, ale też na wielu innych działaniach, takich jak bezpieczeństwo publiczne i świadczenia społeczne, dzięki którym odeszliśmy daleko od gospodarki rządzonej samym rynkiem [Gazeta Wyborcza, 4-5.04.2009]. 
Colander 1998]. W rezultacie wyznacznikiem głównego nurtu jest forma ujęcia, zapewniająca precyzyjność oraz logiczność zbliżoną do nauk ścisłych.

Podejście instytucjonalne nie ignoruje statystyk, ale ma przede wszystkim charakter jakościowy. Polega w dużej mierze na intuicji miast na matematycznych równaniach i prostych logicznych zależnościach. Stwarza pole do skojarzeń dzięki swojej interdyscyplinarności. W charakterze maksymy warto przytoczyć słowa dwóch wybitnych myślicieli. Zdaniem Gunnara Myrdala: „W rzeczywistości nie istnieją problemy 'ekonomiczne'; istnieją po prostu problemy, a te są złożone. Wyjaśnienie, co się rozumie pod terminem problemy 'ekonomiczne' lub czynniki 'ekonomiczne', powinno $\mathrm{w}$ gruncie rzeczy polegać na analizie obejmującej wszystkie determinanty 'pozaekonomiczne'._Z naukowego punktu widzenia istnieje jedyne dopuszczalne rozgraniczenie - jedyne logicznie sensowne: między czynnikami mającymi i nie mającymi znaczenia dla problemu" [Myrdal 1975, s. 54]. Przy takim podejściu korzystanie z dorobku innych dziedzin wiedzy staje się nieodzowne. Zgodnie z przestrogą chętnie dzisiaj cytowanego Friedricha von Hayeka, laureata Nagrody Nobla w dziedzinie ekonomii i doktora prawa: „Ten, kto jest jedynie ekonomistą, nie może być dobrym ekonomistą. Tylko pojedyncze problemy mogą być skutecznie rozwiązane przy wykorzystaniu jednej dyscypliny naukowej" [Hayek 1967, s. 121]. Słowa tego autorytetu o niemałych zasługach dla rozwoju analizy instytucjonalnej nasuwają wniosek, że ten, kto chce zrozumieć gospodarkę, powinien patrzeć poza granice, które wytycza główny nurt ekonomii, i nie może odcinać się od nauk humanistycznych i nauk społecznych innych niż ekonomia.

Z charakterystycznych elementów myślenia instytucjonalistów zaakcentowanych wyżej warto wyciągnąć zwłaszcza te bardziej kompatybilne z ekonomią głównego nurtu, czyli pochodzące głównie z nowej ekonomii instytucjonalnej. Biorąc je pod uwagę, widzimy gospodarowanie jako aktywność jednostek zawierających między sobą transakcje z myślą o własnej korzyści, ale ograniczonych w swej ekonomicznej racjonalności przez instytucje i narażonych na oportunizm innych jednostek. W transakcjach dominuje konflikt interesów. Aby wprowadzić kontrolę działań i wnieść nową harmonie interesów pomiędzy potencjalnymi partnerami, tworzy się w wyniku kolektywnych działań i narzuca za pomocą różnych organizacji ograniczenia, czyli instytucje (J.R. Commons). Mają one na celu zmniejszenie niepewności, a w szczególności - negatywnych konsekwencji niekompletności kontraktów i oportunizmu umawiających się stron. Szczególną uwagę w tym kontekście poświęca się niekompletności kontraktów między pracodawcą i pracownikiem ${ }^{6}$. Niemniej wspomniane ograniczenia rodzą koszty (R.H. Coase, O.E. Williamson),

6 Stosunkowo dobrze opracowane sytuacje to problem agencji (principal-agent problem) i pokusa nadużycia (moral hazard), gdy podmiot, będący właścicielem fizycznych aktywów (principal), zawiera umowę o pracę z pracownikiem bądź menedżerem (agent). Asymetryczna informacja przed lub po zawarciu kontraktu działa zwykle na niekorzyść jednej z dwóch stron kontraktu, mianowicie - pryncypała. Oportunizm pracownika najemnego jest jedną z przyczyn, że kontrakt jest niekompletny i z tego powodu rosną koszty transakcji. 
np. zabezpieczenia za pomocą kontraktów rodzą koszty uzgadniania i egzekwowania kontraktów. Społeczna koordynacja pociąga też za sobą koszty transferu praw własności, koszty zbierania i przetwarzania informacji, koszty poszukiwania kontrahentów itp. Ograniczenie kosztów transakcji, czyli kosztów związanych z monitorowaniem i przestrzeganiem zawartych między ludźmi porozumień i umów, jawi się jako jeden z głównych problemów współczesnej ekonomii instytucjonalnej. Są to koszty o wyraźnie innym charakterze niż koszty produkcji, którymi zajmuje się ekonomia w głównym nurcie.

Powyższy krótki przegląd upoważnia do stwierdzenia, że instytucjonalizm pod ważnymi względami uzupełnia myślenie o gospodarce kultywowane przez główny nurt teorii ekonomii, w tym - przez ekonomię neoklasyczną. Zaakceptowanie przez część współczesnych ekonomistów ograniczeń ludzkiej racjonalności pobudziło rozwój teorii kosztów transakcji, praw własności, niekompletnych kontraktów (zob. [Furubotn, Richter 2000, s. 31-32]). Wymienione nurty badań okazały się przydatne do stworzenia nowej teorii firmy (O.E. Williamson), do wyjaśnienia logiki publicznego wyboru (J.M. Buchanan) i do objaśniania ewolucji rynku i państwa w ramach nowej historii gospodarczej (D.C. North) ${ }^{7}$. Z tych względów można mówić o programie badań w ekonomii wyraźnie odróżniającym się od dominującego paradygmatu. Odmienność to warunek konieczny, jednak nie dostateczny, aby mówić o nowym paradygmacie. Należy postawić pytanie, czy oprócz tego zarysowane podejście oferuje specyficzny pomysł badawczy o wartości eksplanacyjnej.

\section{Na czym polega instytucjonalistyczna alternatywa?}

Przez alternatywę rozumiemy tu inną możliwość ujęcia przedmiotu badań. W kolejnych krokach spróbujemy pokazać, że wyzwanie, jakie tworzy rozwój analizy instytucjonalnej wobec analiz w głównym nurcie ekonomii, to w istocie możliwość innego i stosunkowo spójnego ujęcia procesu gospodarowania.

Współczesna ekonomia opiera się na modelu akceptowanym i rozwijanym przez ekonomistów w dominujących akademickich ośrodkach i czasopismach. Określone upraszczające założenia, dotyczące zachowań ludzi, pozwalają na sprowadzenie złożonego procesu gospodarowania do niewielu zależności przyczynowych w celu lepszego jego zrozumienia i na modelowanie za pomocą narzędzi matematycznych (zob. [Begg, Fischer, Dornbush 2003 i 1991, s. 50]). Na potrzeby tego artykułu wystarczy posłużyć się kanoniczną triadą hipotez „chciwość - racjonalność - równowaga", która według Roberta M. Solowa określa dominujący sposób myślenia o gospodarce [R. Solow; cyt. za: Wojtyna 2008, s. 14]. Zgodnie z tym uproszczeniem rzeczywistości zysk lub użyteczność skłania doskonale poinformowanych konsumentów i producentów do racjonalnych wyborów. Ich aktywność na rynku prowadzi do konkurencji i „naturalnej” skłonności gospodarki do równowagi. Bez

7 Szerzej ekonomia instytucjonalna w tym ujęciu została omówiona w [Ząbkowicz 2003]. 
wiary w tę ostatnią, inaczej mówiąc - bez założenia, że istnieje docelowy, hipotetyczny ośrodek (lub ośrodki) ciążenia gospodarki (multi/equilibrium), pojęcie rynku jako mechanizmu koordynacji byłoby puste.

Podstawy tej wizji zostały zakwestionowane przez instytucjonalizm już w latach 30. XX wieku. Według J.R. Commonsa ,nie ma naturalnej równowagi sił natury, która sprzyjałaby bogactwu narodów dzięki zwykłemu niekontrolowanemu interesowi własnemu" [Wilkin 2011, s. 33]. Interesy i potrzeby bywają sprzeczne i wymagają instytucjonalnych ram, ułatwiających harmonizację. Konkurencja i spontaniczne dostosowania za pośrednictwem rynku nie są drogą do tego celu. To świadoma koordynacja w celu rozwiązywanie konfliktów stanowi rzeczywisty problem ekonomii.

$\mathrm{Z}$ perspektywy instytucjonalistów proces gospodarowania ujęty jest $\mathrm{w}$ ramy stanowionych reguł i niepisanych norm, o ciągłej ewolucji ładu gospodarczego decydują w istocie przekonania, zatem ma znaczenie podłoże kulturowe aktywności społecznej. Ze spontanicznej koordynacji za pośrednictwem cen, która prowadzi gospodarkę do równowagi, akcent zostaje przesunięty na stosunki między ludźmi w strukturach organizacyjnych. Organizacje wraz z ludźmi, którzy je wykorzystują, aby działać na rzecz wspólnych celów i w określonych przypadkach skuteczniej je osiągać, są przedstawiane jako instytucje. Waga przywiązywana do organizacyjnych form koordynacji produkcji i wymiany może być uznana za kluczowy atrybut instytucjonalistycznego ujęcia procesu gospodarowania. Zgodnie z podejściem nowej ekonomii instytucjonalnej liberalne zasady wzajemnych korzyści z wymiany i wolności kontraktu nie wystarczają do zapewnienia egzekwowania zobowiązań, dlatego rynek jest tylko jedną z form organizacji wymiany i zabezpieczenia kontraktów. O.E. Williamson [1985] sposobu na ograniczenie niepewności z powodu braku kompletnych kontraktów i oportunizmu umawiających się stron upatruje w sieci zależności wewnątrz danej firmy lub w układach powiązań między firmami. Douglass C. North [1990] podstawowe znaczenie w skutecznym egzekwowaniu kontraktów (i w zmniejszeniu związanych z tym kosztów) przypisuje we współczesnej odpersonalizowanej gospodarce instytucjom państwa, takim jak policja czy sądownictwo, które wymuszają przestrzeganie umów lub pomagają w rozstrzyganiu sporów. W sumie reguły gry zależą od modeli mentalnych, układów politycznych i przyjętej w społeczeństwie hierarchii wartości, czyli od szeroko pojętej kultury [Sjöstrand 1993]. Praktykowane w określonych strukturach sprawiają, że funkcjonuje gospodarka.

W poszukiwaniu alternatywnego ujęcia gospodarki skorzystamy z asocjacji, jaką czyni interdyscyplinarny instytucjonalizm z naukami o zarządzaniu. Osią tej intelektualnej konstrukcji jest jedno z kluczowych pojęć w tej dziedzinie, mianowicie governance. Pod tym terminem kryją się instytucje pomagające rozwiązywać konflikty, jakie powstają w procesie szeroko pojętego kontraktowania. Corporate governance oznacza rozwiązywanie konfliktów w ramach gospodarującej organizacji, a public governance odnosi się do koordynacji interesów gospodarczych 
w strukturach państwa. Waga przywiązywana do tych organizacyjnych form koordynacji istotnie odróżnia instytucjonalistyczne podejście od głównego nurtu myśli ekonomicznej, gdzie pojęciem organizującym jest konkurencja i analizy prowadzone są w intelektualnych ramach ,rynku”.

Wykorzystując pojęcie organizacyjnych form koordynacji (governance structure $)^{8}$, można skonstruować holistyczny obraz porządku gospodarczego. Chociaż różnorodność myśli w ekonomii instytucjonalnej może sprawiać kłopot przy wykonywaniu tego zadania, wydaje się, że dorobek O.E. Williamsona stworzył dostateczną bazę, aby je podjąć ${ }^{9}$ W nawiązaniu do swojej publikacji z 2011 roku przedstawiam kolejną próbę ${ }^{10}$. Inspiracją do niej jest idea, że rynek jest tylko jedną z możliwych struktur koordynacji, w pewnych bowiem okolicznościach hierarchiczna organizacja może zapewnić niższe koszty transakcji ${ }^{11}$. Według O.E. Williamsona [1985] funkcjonowanie zarówno rynku, jak i firmy opiera się na regułach i konwencji. Sankcjonują one pewne zachowania i ewoluują tak, aby zmniejszyć koszty transakcji. Dokonywanie transakcji na rynku związane jest z kosztami; rodzi je zbieranie informacji, a szczególnie trudności z ustaleniem istotnych cen; rodzi je także negocjowanie kontraktów. Świadomość tych kosztów prowadzi do poszukiwania różnych struktur koordynacji. Jeśli koszty zawierania odrębnego kontraktu dla każdej transakcji rosną, rośnie znaczenie firmy, czyli rośnie atrakcyjność świadomego zarządzania w porównaniu z mechanizmem cenowym. Pomiędzy „,czystymi” strukturami firmy i rynku funkcjonują w gospodarce formy hybrydalne, do których można zaliczyć np. sieci biznesowe. Obrazu dopełniają biurokratyczne struktury państwa [Williamson 1999]. Podobnie jak firmy, także rządy, urzędy regulacyjne, sądy potrzebują struktury zarządzania, która „narzuca porządek, minimalizuje konflikt i zapewnia wzajemne korzyści” [Williamson 2011].

Omówione struktury koordynacji w gospodarce przedstawić też można za pomocą schematu (zob. rys. 1). Funkcjonują one w ramach ładu instytucjonalnego, który na rysunku został przedstawiony jako nadbudowa. Ład instytucjonalny tworzy się i ewoluuje w wyniku wzajemnego oddziaływania powszechnie uznawanych wartości, reguł społecznego współżycia i działań organizacji uwzględniających te

8 Pojęcie często thumaczone jest na polski jako struktura zarządzania. Jednym z przypisywanych mu znaczeń jest „matryca instytucjonalna, gdzie zapewnia się integralność transakcji” [Stankiewicz 2010, s. 584].

9 Według Furubotna i Richtera [2000, s. 176] analiza Williamsona stanowi jądro nowej ekonomii instytucjonalnej, którą zainicjowały prace Coase’a oraz Alchiana i która rozwinęła się współcześnie w nową historię gospodarczą D.C. Northa oraz w ekonomiczne teorie polityki.

${ }^{10}$ Niniejszy artykuł nawiązuje do: Governance, government, and economic policies, Research Papers of Wrocław University of Economics (Prace Naukowe Uniwersytetu Ekonomicznego we Wrocławiu), no. 3(15), Ekonomia Economics, ed. B. Klimczak, Wrocław 2011, s. 46-57.

${ }^{11}$ Oprócz zmniejszenia kosztów transakcji racją istnienia firmy są także korzyści z zarządzania wiedzą (knowledge governance). Szczególną korzyść komparatywną daje ukryta wiedza subiektywna (tacit knowledge), czyli „specjalny rodzaj wymiany informacji, który generuje większą wiedzę niż 'suma' wiedzy indywidualnych uczestników [wymiany]” [Langlois; cyt. za: Hardt 2009, s. 42]. 
reguły i wartości. Natomiast schematyczne przedstawienie porządku gospodarczego, które powstało z inspiracji dorobkiem Williamsona, znajduje się niżej. Wiodące w tej części pojęcie governance structures odnosi się zarówno do struktur organizacyjnych na różnych szczeblach działalności gospodarczej, jak i do reguł wewnątrz organizacji. Reguły, zasady i rutynowe wzorce koordynują zachowania ludzi w organizacji i sprawiają, że sztywne struktury żyją.

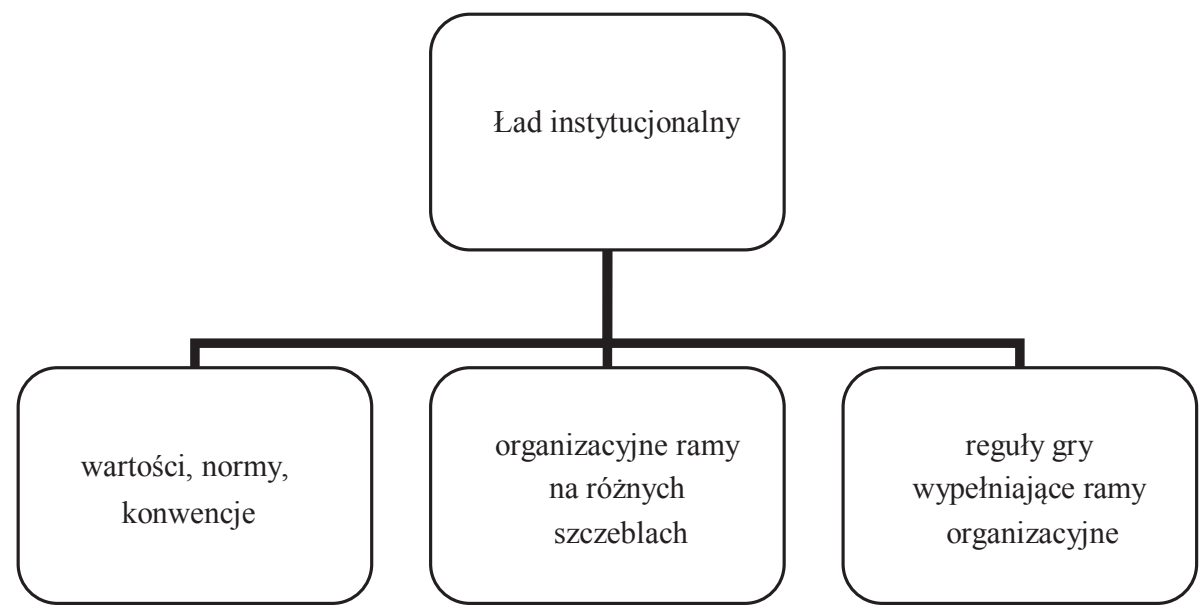

organizacyjne formy koordynacji produkcji i wymiany (governance structure)

na szczeblu gospodarki narodowej public bureau

na szczeblu pośrednim - relational contracting

na szczeblu mikro - corporate governance, market governance

Rys. 1. Ujęcie ładu instytucjonalnego i porządku gospodarczego

Źródło: opracowanie własne. 
Przywołana wizja skłania do trójszczeblowego ujęcia porządku gospodarczego. Na poziomie mikroekonomicznym koordynacja opiera się na mechanizmie cenowym regulującym popyt i podaż (market governance) lub na własności i hierarchii, które spajają gospodarującą organizację. Różne układy praw własności i kontroli pozwalają zabezpieczać się przed skutkami niedotrzymania umowy przez partnera w strukturach korporacji zintegrowanych pionowo i poziomo (corporate governance). Inny sens ma poleganie przez firmy na sieci relacji (relational contracting) w celu zmniejszania niepewności działań i to skłania do wyodrębnienia szczebla pośredniego między poziomem mikroekonomicznym i strefą państwa. Problemy, które mogą wyniknąć w przyszłości z powodu niekompletności długoterminowego kontraktu, mogą łagodzić procedury, które nie polegają na prawnych sankcjach i praktykowane są przez firmy prywatne wzajemnie od siebie zależne, bez udziału państwa [Williamson 1993]. Koordynacja na tym poziomie odbywa się na zasadzie porozumień między niezależnymi podmiotami ekonomicznymi. Struktury sieciowe mogą opierać się na porozumieniach między niezależnymi partnerskimi firmami (alianse strategiczne, kartele, joint ventures itp.), a także na powiązaniach z dostawcami, klientami i innymi podmiotami z otoczenia firmy. Kolejny szczebel należy do państwa, które koordynuje aktywność gospodarczą, w szczególności egzekwuje dotrzymywanie umów, dzięki legitymizacji przymusu (public governance/public bureau modes of governance).

Proponowane tutaj ujęcie ładu instytucjonalnego i porządku gospodarczego przywodzić może na pamięć schemat O. Williamsona, znany z jego często przywoływanego artykułu [Williamson 2000]. Warto więc zaznaczyć, iż różni się od niego pod paroma względami. Przypomnijmy, że struktura Williamsona składa się z czterech poziomów, przy czym poziom wyższy zawsze tworzy ograniczające ramy dla działalności na szczeblu niższym. Poziom 1, najwyższy, odnosi się do instytucji nieformalnych, tworzonych w sposób spontaniczny i ewolucyjny oraz charakteryzujących się długim trwaniem. Poziom 2 odnosi się do instytucji formalnych (instytucji prawa), powstających w wyniku żmudnego procesu politycznego, w którym udział biorą partie polityczne, sądownictwo i biurokracja publiczna. Poziom 3 należy do koordynacji w strukturach firmy, która odbywa się w stosunkowo krótkim czasie. Poziom 4 to krótkookresowe decyzje w ujęciu bliskim ekonomii neoklasycznej [Williamson 2000, s. 597].

Zgodnie z zamysłem tej pracy, rys. 1 prezentuje próbę rozciągnięcia znaczenia pojęcia governance poza pierwotny zakres. W 2000 roku Williamson, mówiąc o institutions of governance, przypisuje to pojęcie przede wszystkim poziomowi 3 [Williamson 2000, s. 608], któremu odpowiada szczebel mikro i zakres corporate governance na rys. 1. Autor w różnych miejscach i różnych tekstach używa tego pojęcia w sposób niejednoznaczny. Już w przywoływanym artykule zaznaczył, że między poziomem 3 (institutions of governance) i poziomem 2 (institutional environment) mieści się wiele zagadnień, które mogą być interpretowane jako governance of contractual relations [Williamson 2000, s. 608]. Wartość dodana przez 
autorkę tej pracy wydaje się sprowadzać do trzech punktów. Po pierwsze, zgodnie z niniejszą propozycją, określamy governance structures jako organizacyjne formy koordynacji produkcji i wymiany. Po drugie, w takim sensie można je dostrzec zarówno na szczeblu mikro, jak i na szczeblu pośrednim oraz na szczeblu gospodarki narodowej, o czym przekonywał opis powyżej. Tym samym pojęcie zaczyna pełnić rolę narzędzia holistycznego podejścia do gospodarki. Wreszcie, przestrzeń między poziomem 3 (institutions of governance) i poziomem 2 (institutional environment), o której pisał Williamson, opis niniejszy zapełnia konkretnymi formami więzi i kontraktów, obserwowanymi we współczesnej gospodarce (szczebel pośredni na rys. 1).

W sumie ekonomia instytucjonalna oferuje odrębne podejście do gospodarki, a pojęcie governance structure można uznać za jej specyficzny pomysł badawczy. Kryją się pod nim formalne i nieformalne instytucje pomagające rozwiązywać konflikty, jakie powstają w procesie szeroko pojętego kontraktowania, także w ramach organizacji. Złożony proces gospodarowania został ujęty za pomocą kilku odmian governance structure powiązanych wzajemnie, składających się na spójną i pojemną całość.

Wydaje się, że ustalenia jak wyżej mają tę wartość, że tworzą grunt do dyskusji. Wizja gospodarki jako procesu wieloszczeblowej, świadomej koordynacji w organizacyjnych ramach, który ma na celu ograniczanie konfliktu i kosztów transakcji, zasługuje na uwagę ekonomistów. Czy taki klucz do społecznego dobrobytu zyska uznanie większości, może pokazać jedynie pogłębiona dyskusja. Jest to myślenie odmienne od tradycyjnego przedmiotu rozważań ekonomistów, który stanowi efektywny wybór za pomocą niezależnego od ludzkich planów mechanizmu rynkowego. Zmiana perspektywy wraz z odmiennym pomysłem na ujęcie gospodarki tworzą podstawy, aby rozwinął się nowy paradygmat.

\section{Zakończenie}

Korzystając z dorobku współczesnej ekonomii instytucjonalnej, można zbudować model gospodarki. Przesłankę stanowi uznanie kulturowych korzeni gospodarowania, z których wyrastają normy i formalne reguły, dzięki którym istnieje i funkcjonuje społeczeństwo. Za pomocą pisanych i niepisanych norm społeczeństwo koordynuje swoje wysiłki w celu obniżenia kosztów transakcji w ramach różnych struktur. Wyróżnienie owych organizacyjnych ram koordynacji (governance structures) zapewnia spójność obrazu. Jest to podejście holistyczne, które zdaje się dość pojemne, aby objąć różnorodne motywacje ludzi i stosunki między nimi, a zarazem - interdyscyplinarne, bo w tym celu korzysta z dorobku kilku dyscyplin nauki (ekonomia, polityka, zarządzanie). Uznanie governance structure za centralne pojęcie może okazać się przydatne, aby na nowo modelować i objaśniać gospodarkę rynkową. Wizja ta nie neguje rynku i konkurencji, czyniąc je jednakże tylko jedną z form 
koordynacji na najniższym poziomie, zasadniczo przebudowuje pespektywę badawczą.

Jest to zatem jedna z szans na narodziny nowego paradygmatu w ekonomii. W celu wyostrzenia prezentowanego w tym artykule obrazu warto odwołać się do opinii Roberta Heilbronera: „Odkrycie nowego, integrującego modelu czy paradygmatu byłoby największym triumfem nauk społecznych naszych czasów. Na razie model taki nie istnieje. Musimy więc uznać głębokie ograniczenie analizy ekonomicznej, dla którego nie widać obecnie rozwiązania" [Heilbroner 1985, s. 119-120]. Mówiąc o paradygmacie, autor ma na myśli powstanie teorii zmian społecznych jednoczącej ekonomię, socjologię i nauki polityczne i stwierdza, że nie widać syntezy, która wyjaśniałaby charakter subtelnych powiązań między mechanizmem ekonomicznym a sferą polityczną i społeczną ludzkiego działania. Z pewnością takiego warunku nie spełnia wysublimowany ,neoklasyczny” paradygmat, przetwarzany w głównym nurcie teorii ekonomii. Faktycznie nie istnieje paradygmat w metafizycznym sensie, jak go rozumie R. Heilbroner, tj. obraz świata stosunków społecznych. Jednak imponujący postęp we współczesnej ekonomii instytucjonalnej skłania do namysłu nad ostatnim z cytowanych zdań. Koncepcja governance structure, wspólna dla kilku co najmniej nauk społecznych, i zbudowana na niej wizja gospodarowania wydaje się pragmatycznym pomysłem badawczym, który pozwoli rozumieć procesy ekonomiczne przyszłości lepiej niż modelowy homo oeconomicus wywodzący się z okresu wczesnokapitalistycznej przedsiębiorczości. Wyłania się zatem paradygmat $\mathrm{w}$ skromniejszym, pragmatycznym wymiarze.

\section{Literatura}

Aoki M., 2001, Towards a Comparative Institutional Analysis, The MIT Press, Cambridge Ma., London.

Begg D., Fischer S., Dornbusch R., 1991, Economics, $3^{\text {rd }}$ edition, McGraw-Hill Book Company, London (wyd. pol.: Mikroekonomia, PWE, Warszawa 2003).

Bromley D.W., 1989, Economic Interests and Institutions. The Conceptual Foundations of Public Policy, Basil Blackwell, New York.

Chavance B., 2009, Institutional Economics, Routledge, London.

Coase R.H., 1984, The New Institutional Economics, Journal of Institutional and Theoretical Economics, no. 140, s. 229-231.

Colander D.C., 2000, The death of neoclassical economics, Journal of the History of Economic Thought, vol. 22, no. 2 .

Commons J.R., 1968, Legal Foundations of Capitalism, University of Wisconsin Press, Madison (wyd. oryg.: McMillan Co., 1932).

Furubotn E.G., Richter R., 2000, Institutions and Economic Theory. The Contribution of the New Institutional Economics, The University of Michigan Press, Ann Arbor.

Godłów-Legiędź J., 2010, Współczesna ekonomia. Ku nowemu paradygmatowi?, C.H. Beck, Warszawa.

Hall P., Taylor R.C., 1996, Political science and the three new institutionalisms, Political Studies, XLIV, s. 936-957. 
Hardt Ł., 2009, The history of transaction cost economics and its recent developments, Erasmus Journal for Philosophy and Economics, vol. 2, issue 1, Summer.

Hayek F.A., 1967, Studies in Philosophy, Politics and Economics, Routledge \& Kegan Paul, London.

Heilbroner R.L., 1985, Ekonomia a rzeczywistość, [w:] Ponad ekonomia, red. J. Grosfeld, Państwowy Instytut Wydawniczy, Warszawa.

Hodgson G., 2015, Conceptualizing Capitalism. Institutions, Evolution, Future, Chicago University Press, Chicago.

Landreth H., Colander D.C., 1998, Historia myśli ekonomicznej, przekład A. Szeworski, Wydawnictwo Naukowe PWN, Warszawa.

Myrdal G., 1975, Przeciw nędzy w świecie. Zarys światowego programu walki z nędza, Państwowy Instytut Wydawniczy, Warszawa.

North D.C., 1990, Institutions, Institutional Change and Economic Performance, Cambridge University Press, New York.

Sjöstrand S.E., 1993, On institutional thought in the social and economic sciences, [in:] Institutional Change. Theory and Empirical Findings, ed. S.E. Sjöstrand, M.E. Sharp, Armonk, New York, London, England.

Stankiewicz W., 2004, Ekonomika instytucjonalna. Narodziny i rozwój, Wydawnictwo Biura Badań Strategicznych Prywatnej Wyższej Szkoły Businessu i Administracji, Warszawa.

Stankiewicz W., 2010, Instytucjonalizm o zarządzaniu: Nobliści z ekonomii w roku 2009, Ekonomista, nr 4.

Wilkin J., 2009, Czy ekonomia może być piękna? Rozważania o przedmiocie i metodzie ekonomii, Ekonomista, nr 3.

Wilkin J., 2011, Institutional equilibrium. What is it about and what is its role int the economy?, Ekonomia/Economics, no. 3(15), Wroclaw University of Economics.

Williamson O.E., 1985, The Economic Institutions of Capitalism, Firms, Markets, Relational Contracting, Free Press, New York (wyd. pol.: Ekonomiczne instytucje kapitalizmu, Wydawnictwo Naukowe PWN, Warszawa 1998).

Williamson O.E., 1993, Comparative economic organization: the analysis of discrete structural alternatives, [in:] Institutional Change. Theory and Empirical Findings, ed. S.E. Sjöstrand, M.E. Sharp, Armonk, New York, London, England.

Williamson O.E., 1999, Public and private bureaucracies: a transaction cost economics perspectives, Journal of Law, Economics, and Organization, vol. 15, issue 1, s. 306-342.

Williamson O.E., 2000, The new institutional economics: taking stock, looking ahead, Journal of Economic Literature, vol. XXXVIII, s. 595-613, https://campus.fsu.edu/bbcswebdav/orgs/econ_office_org/Institutions_Reading_List/02._Institutional_Quality_and_Growth/Williamson,_O._E.-_ The_New_Institutional_Economics\%3B_Taking_Stock,_Looking_Ahead.

Williamson O.E., 2011, (rozmowa z), W'sibsk̄ość popłaca, Gazeta Wyborcza, 21.02.2011.

Wojtyna A., 2008, Współczesna ekonomia - kontynuacja czy poszukiwanie paradygmatu?, Ekonomista, $\mathrm{nr} 1$.

Ząbkowicz A., 2003, Współczesna ekonomia instytucjonalna wobec głównego nurtu ekonomii, Ekonomista, $\mathrm{nr} 6$. 